\title{
SEVEN NEW FLEA BEETLES FROM THE WEST INDIES (COLEOPTERA-CHRYSOMELID $Æ)^{1}$
}

\author{
By Doris H. Blake \\ Arlington, Va.
}

This paper contains descriptions of seven new flea beetles from Jamaica, Hispaniola and Puerto Rico in the collection of the Museum of Comparative Zoology at Cambridge. Five of these were collected by P. J. Darlington.

\section{Lactica xanthotrachela n. sp.}

Fig. 1

From 3-4 mm. in length, elongate oblong, shining, dark blue or green with yellow head and thorax and deep brown antennæ, mouthparts and legs, hind legs usually with metallic lustre.

Head with interocular space over half its width, shining, smoothly rounded over occiput with a large puncture on either side near eye and obsolete small punctures on front, tubercles more or less distinctly marked, the space between antennal sockets a little produced and rounded; mouthparts dark. Antennæ with slightly paler basal joints, deep brown otherwise, third joint shorter than fourth, remainder subequal. Prothorax not quite twice as broad as long with almost straight sides and deep and very slightly sinuate basal sulcus; surface shining and finely punctate. Elytra more distinctly punctate than prothorax, very shining, green or blue, the humeri well marked by a short intrahumeral sulcus, otherwise the elytra smoothly convex. Epipleura wide but disappearing before the apex. Body beneath lustrous, the pale color of thorax extending down to the coxæ of the middle legs, rest of undersurface lustrous black or with metallic blue color, and finely pubescent. Legs dark, the hind ones, at least, with metallic lustre. First tarsal joint of hind legs long, claws appendiculate. Length 3.1-4.1 mm.; width 1.5-2 $\mathrm{mm}$.

1 Published with a grant from the Museum of Comparative Zoölogy at Harvard College. 
Type male and 5 paratypes M.C.Z. Type No. 27797. 1 paratype in U.S.N.M. Cat. No. 58723.

Type locality.-Mandeville, Jamaica, collected by A. E. Wright.

Other localities.-Pt. Antonio, Jamaica, collected by A. E. Wright, Dec. 1931; “'Jamaica,'” collected by L. G. Perkins, in the Stuart T. Danforth collection.

Remarks.-In coloration this species is similar to a great many others that occur on the continents both of North and South America, but upon careful comparison I have not been able to find any other species that entirely corresponds with this Jamaica species. For instance, L. iris (Oliv.) of North America has pale front and middle legs; L. elegans Harold of Colombia has a pale margin on the elytra, L. semiviolacea Jac. and L. mexicana Jac. and $L$. hogei Jac. are all much larger.

\section{Lactica darlingtoni $n$. sp.}

$$
\text { Fig. } 2
$$

From 3-3.5 mm. in length, elongate oblong, shining, deep blue or blue green with black antennæ, legs and undersurface, the two latter often with a blue or green lustre; very finely punctate.

Head with interocular space more than half its width, very polished over occiput and front with a median line between tubercles extending upwards (in one specimen) to end in a small depression in middle of the front; a large puncture on either side near the eye; frontal carina between antennal sockets somewhat produced, rounded. Antennæ scarcely reaching the middle of the elytra, 3rd joint shorter than 4th, the basal joints with a metallic lustre. Prothorax twice as wide as long with slightly curved sides and explanate margin and a well marked basal sulcus, surface polished, very finely punctate. Elytra elongate, the humeri small with a short intrahumeral sulcus and slight transverse depression below basal callosity; surface polished, very finely but distinctly punctate throughout. Epipleura broad, gradually diminishing and disappearing before the apex. Body beneath usually with a metallic lustre, very finely pubescent. 
First joint of hind tarsi long, claws appendiculate. Length 3.1-3.5 mm.; width $1.5-1.7 \mathrm{~mm}$.

Type male and 3 paratypes M.C.Z. Type No. 27798. 1 paratype in U.S.N.M. Cat. No. 58724.

Type locality.-Whitfield, Blue Mts., Jamaica, elevation 4500 feet, collected in Aug. 1930 by P. J. Darlington.

Remarks.-In coloration this is similar to $L$. violacea Jac. described from Guatemala and Panama. It differs from that species in being a little more elongate and with extremely fine punctation which is the same throughout, not disappearing at the apex as in violacea. The sculpture of the head with its distinctly marked frontal tubercles also appears different, and the sulcus across the prothorax is not sinuate at all but straight.

\section{Lactica porphyrea n. sp.}

Fig. 3

From 2.5-3 mm. in length, ovate, shining yellowish or reddish with violet elytra and dark abdomen; only faint traces of a basal sulcus across the prothorax most marked on each side at the limiting ends; elytra distinctly and rather densely punctate.

Head with interocular space over half its width, frontal tubercles and space between the antennal sockets somewhat elevated with a depressed spot or area above the tubercles, the surface of the occiput and front and frontal carina densely and shallowly punctate and alutaceous; a large puncture on either side of front near the eye. Antennæ more than half the length of the beetle, third joint shorter than fourth, remainder subequal and rather heavy. Prothorax fully twice as wide as long with arcuate sides and narrow explanate margin; surface smooth, polished and fairly alutaceous with sparse punctation; across base an ill marked and, in some specimens, very indistinct trace of sulcus, the rather faint limiting depressions at either end the most distinct part of it. Scutellum usually deep reddish brown. Elytra with small humeri and a slight basal callosity, very shiny deep violet, with dense distinct punctation in basal half becoming smoother near the apex. Epipleura wide, gradually diminishing 
to end shortly before the apex. Body beneath shining yellowish or reddish with dark brown abdomen, very finely pubescent. Hind tibiæ with a short spur, first tarsal joint of hind legs long, claws appendiculate. Length 2.6-2.9 mm.; width 1.5-1.6 mm.

Type male M.C.Z. Type No. 27799 and four paratypes, 1 in the U.S.N.M. Cat. No. 58725.

Type locality.-Mt. Diego de Ocampo, circa 3-4000 ft. elevation, Dominican Republic, collected in July 1938 by P. J. Darlington.

Remarks.- The extremely indistinct sulcus on the prothorax of many of the specimens at first confuses one as to the generic place of this beetle, but Lactica seems to be the genus to which it most closely corresponds.

\section{Lactica megaspila n. sp.}

Fig. 5

About $3 \mathrm{~mm}$. in length, oblong ovate, shining, yellow brown, antennæ with the outer joints dark, elytra with four large dark spots having a greenish lustre, two at base and the other two at the apex of the elytra.

Head rather deeper brown on the occiput, possibly with aenous lustre in some specimens, densely and obsoletely punctate with a few larger punctures on inner side near the eye; frontal tubercles well marked with a depression above, the space between the antennal sockets a little produced; lower front rather short; interocular space over half the width of the head. Antennæ extending to the middle of the elytra, third joint shorter than the fourth, remainder subequal, the three basal joints paler. Prothorax not twice as broad as long, moderately convex with a wide explanate margin on sides and a clearly marked basal sulcus deepest at limiting ends; surface finely punctate. Elytra shining yellow brown, each with a basal and larger apical spot, the basal spot extending nearly across the base, the apical spot extending from the middle almost to the apex, in the apical spot an aeneous lustre; a short intrahumeral sulcus and depression behind the basal callosity; surface shining, very faintly punctate, a wide explanate margin along the sides. Epipleura 
wide, gradually disappearing before the apex. Body beneath pale, shining beneath the short pale pubescence; hind tibiæ with small spur, first tarsal joint moderately long, claws appendiculate. Length $3.1 \mathrm{~mm}$; width 1.6 $\mathrm{mm}$.

Type male M.C.Z. Type No. 27800.

Type locality.-Villalba, Puerto Rico, collected by C. M. Matos June 28, 1934, in the Stuart T. Danforth collection.

Remarks.-There are two species from Central America that have somewhat similar markings, - L. nigromaculata Jac. with four small basal spots and a large apical spot but with a pale undersurface and pale femora; and $L$. variabilis Jac. which has two basal spots and two apical spots. The second species also has quite differently colored legs.

Pseudoepitrix hottensis n. sp.

Fig. 4

About $2.5 \mathrm{~mm}$. in length, elongate, shining reddish brown, outer joints of antennæ and undersurface deeper brown in color; pronotum densely and rather coarsely punctate.

Head with interocular space half its width, occiput rounded, not very shiny but finely alutaceous, a circle of fine punctures in front and over the indistinct tubercles, a sulcus running from antennal sockets up to eye; antennal sockets situated about midway down front of head, lower front tapering. Antennæ extending to the middle of the elytra, third joint shorter than fourth, last five joints darker. Prothorax not twice as wide as long with only slightly curved and nearly straight sides, having a prominent anterior angle under eye; a well marked and somewhat sinuate basal depression; surface finely alutaceous, somewhat shiny, moderately coarsely and densely punctate. Elytra with the striate punctures coarser in basal half, becoming fine at apex, basal callosities well marked and a transverse impression below them. Body beneath deeper brown, shining, lightly pubescent, legs yellow brown, tibiæ not sulcate, first tarsal joint not so 
long as the remaining joints together, claws appendiculate. Length $2.5 \mathrm{~mm}$; width $1.2 \mathrm{~mm}$.

Type male M.C.Z. Type No. 27801.

Type locality.-Desbarriere, Mt. LaHotte, Haiti, about 4000 ft. elevation, collected Oct. 12-14, 1934, by P. J. Darlington.

Remarks.-This is the second species to be described from Hispaniola. P. hispaniola Blake, described from the Dominican Republic, is more robust with a much more densely and coarsely punctate pronotum, and has a differently shaped ædeagus.

\section{Pseudoepitrix punctatissima n. sp. \\ Fig. 7}

About $2 \mathrm{~mm}$. in length, elongate oblong, moderately convex, shining, very dark reddish brown, almost piceous, with densely and coarsely punctate pronotum and elytra; legs and antennal joints 3-6 and 10 and 11 pale.

Head with interocular space fully half its width; occiput rounded, distinctly punctate, a deeply impressed line straight across front over frontal tubercles joining with a sulcus about inner and upper side of eye ; frontal tubercles somewhat elevated; space between antennal sockets narrow, and lower front to labrum short, labrum long and paler in color. Antennæ not reaching the middle of the elytra, joints 3-6 and 10 and 11 pale, outer joints heavier. Prothorax not twice as wide as long, rather convex, with prominent anterior angle under eye and tooth at basal angle, basal margin a little sinuate, a shallow depression along base; anterior margin a little paler reddish brown; surface shining, densely, deeply and coarsely punctate. Elytra with rounded basal callosity and depression below, convex, very shining dark reddish brown, coarsely striate punctate, the punctures near the suture dense and a little confused and at apex becoming fine, on sides next to margin deeply impressed. Epipleura not reaching apical angle. Body beneath shining deep reddish brown, with paler legs. Anterior coxal cavities open, hind tibiæ not grooved, claws appendiculate. Length $2 \mathrm{~mm}$.; width 1 $\mathrm{mm}$. 
Type female M.C.Z. Type No. 27802.

Type locality.-Desbarriere, Mt. LaHotte, about 4000 feet elevation, Haiti, collected Oct. 12-14, 1934, by P. J. Darlington.

Remarks.-This species is more convex than the other species of Pseudoepitrix from the West Indies, and it has short antennæ and much coarser punctation, which near the suture of the elytra is confused. It may possibly belong to a different genus.

\section{Aphthona fraterna n. sp.} Fig. 6

About $2 \mathrm{~mm}$. in length, ovate, shining reddish brown with yellow antennæ having joints 6-9 black; elytra very finely striate punctate.

Head with interocular space a little more than half its width, smoothly rounded over occiput, frontal tubercles indistinct, a narrow carina from between antennal sockets down to labrum, a lightly impressed line on either side of forehead running up from short sulcus near eye. Antennæ scarcely reaching the middle of the elytra, joints 3 and 4 subequal and shorter than 5, joints 6-9 black. Prothorax not twice as wide as long with obliquely cut anterior angles, only slightly curved, nearly straight sides, and basal margin forming an oblique angle near sides, disk polished, impunctate. Elytra polished, convex, with out depressions, with faintly striate punctation becoming indistinct at apex. Body beneath shining reddish brown, anterior coxal cavities open, hind tibiæ sulcate, with a small spur at apex; claws simple. Length $1.8 \mathrm{~mm}$.; width $1.2 \mathrm{~mm}$.

Type female, M.C.Z. Type No. 27803.

Type locality.-Desbarriere, Mt. LaHotte, Haiti, near 4000 ft., collected Oct. 12-14, 1934, by P. J. Darlington.

Remarks.-This species is closely related to $A$. insolita Melsh. from North America and A. fulvipennis Jac. from Guatemala. All three are reddish brown beetles having the antennæ pale with the outer joints in part dark. All have very lightly striate-punctate elytra. A. fulvipennis from its description appears to resemble $A$. insolita in the 
sculpture of the head in that the frontal tubercles are elevated. In $A$. fraterna the tubercles are not even distinctly marked and the lower front is excavated with only a very narrow ridge running down the front between the antennal sockets. $A$. insolita has a quite different face, particularly in the lower front. It has also very fine punctures on the pronotum, the antennæ are heavier and the entire beetle is more convex than A. fraterna.

Explanation of Plate 14

Fig. 1. Lactica xanthotrachela, n. sp.

Fig. 2. Lactica darlingtoni, n. sp.

Fig. 3. Lactica porphyrea, n. sp.

Fig. 4. Pseudoepitrix hottensis, n. sp.

Fig. 5. Lactica megaspila, n. sp.

Fig. 6. Aphthona fraterna, n. sp.

Fig. 7. Pseudoepitrix punctatissima, n. sp. 


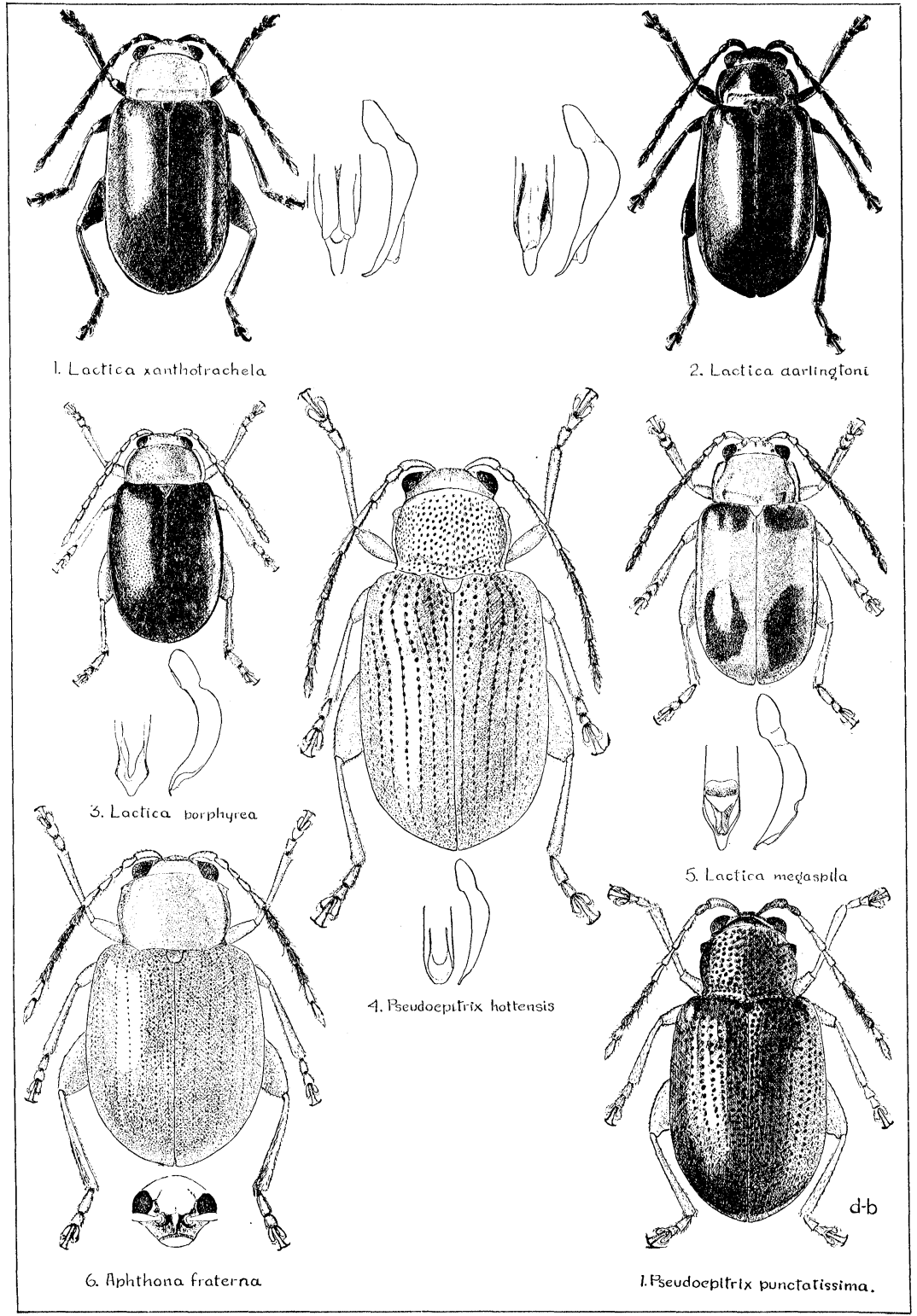



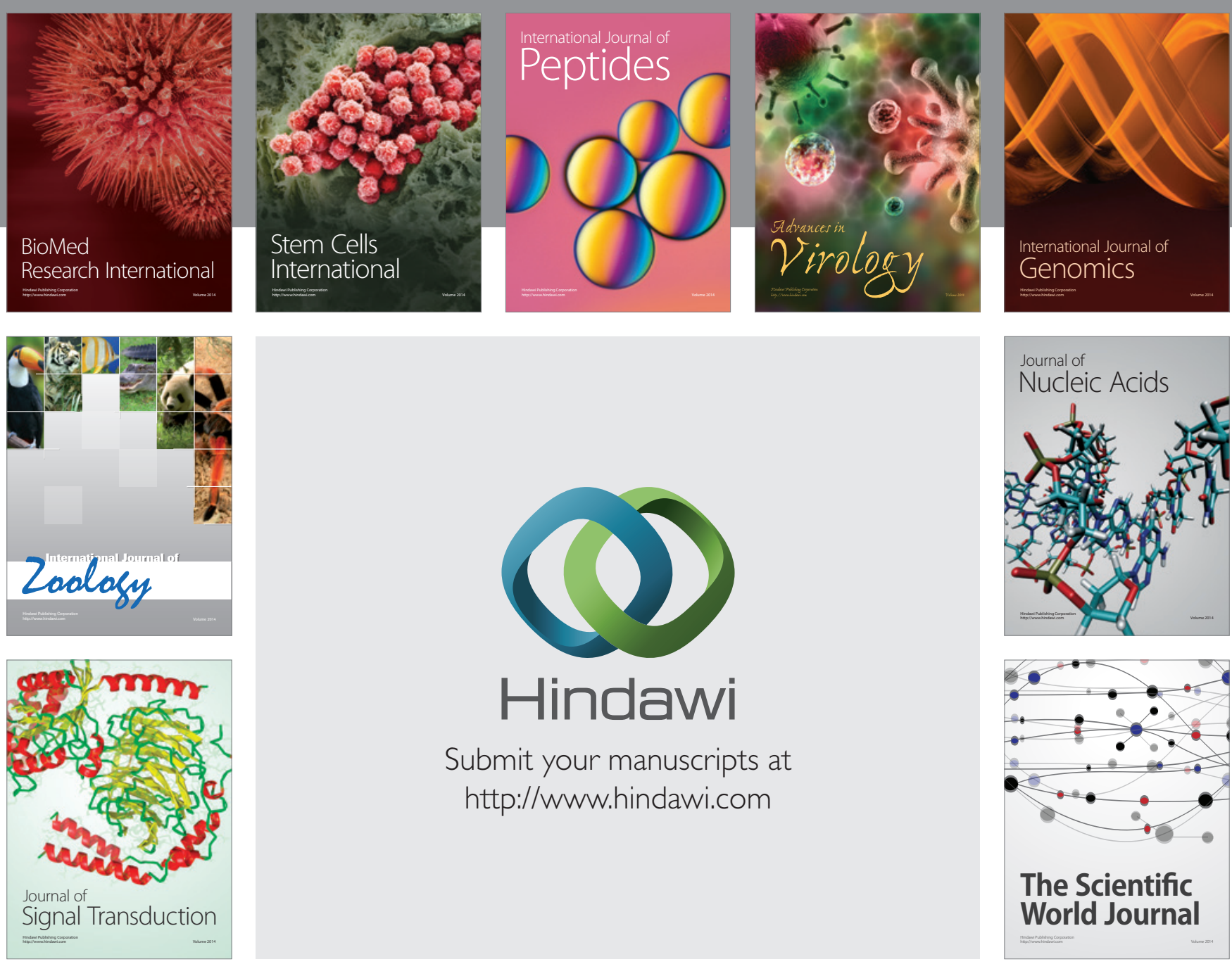

Submit your manuscripts at

http://www.hindawi.com
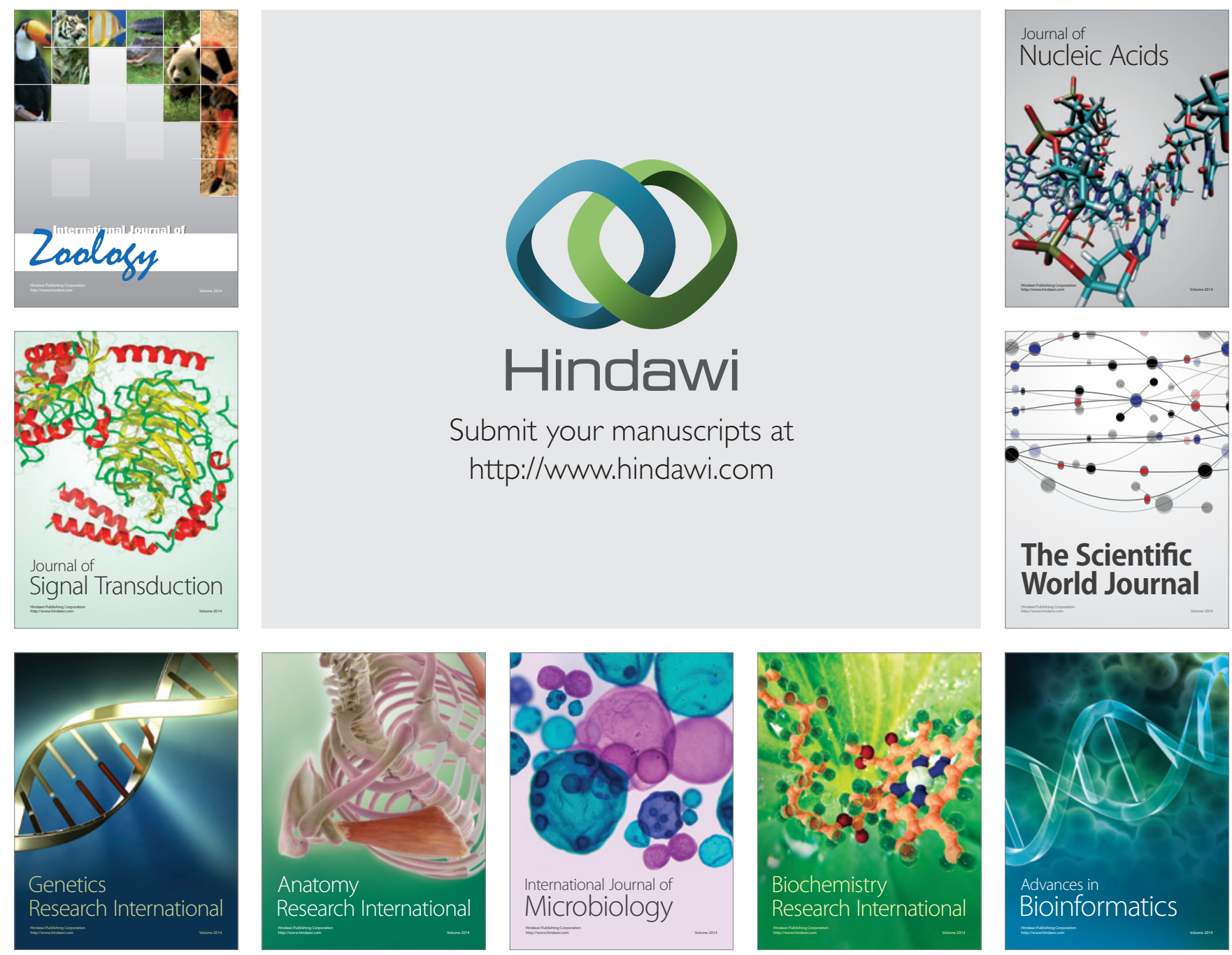

The Scientific World Journal
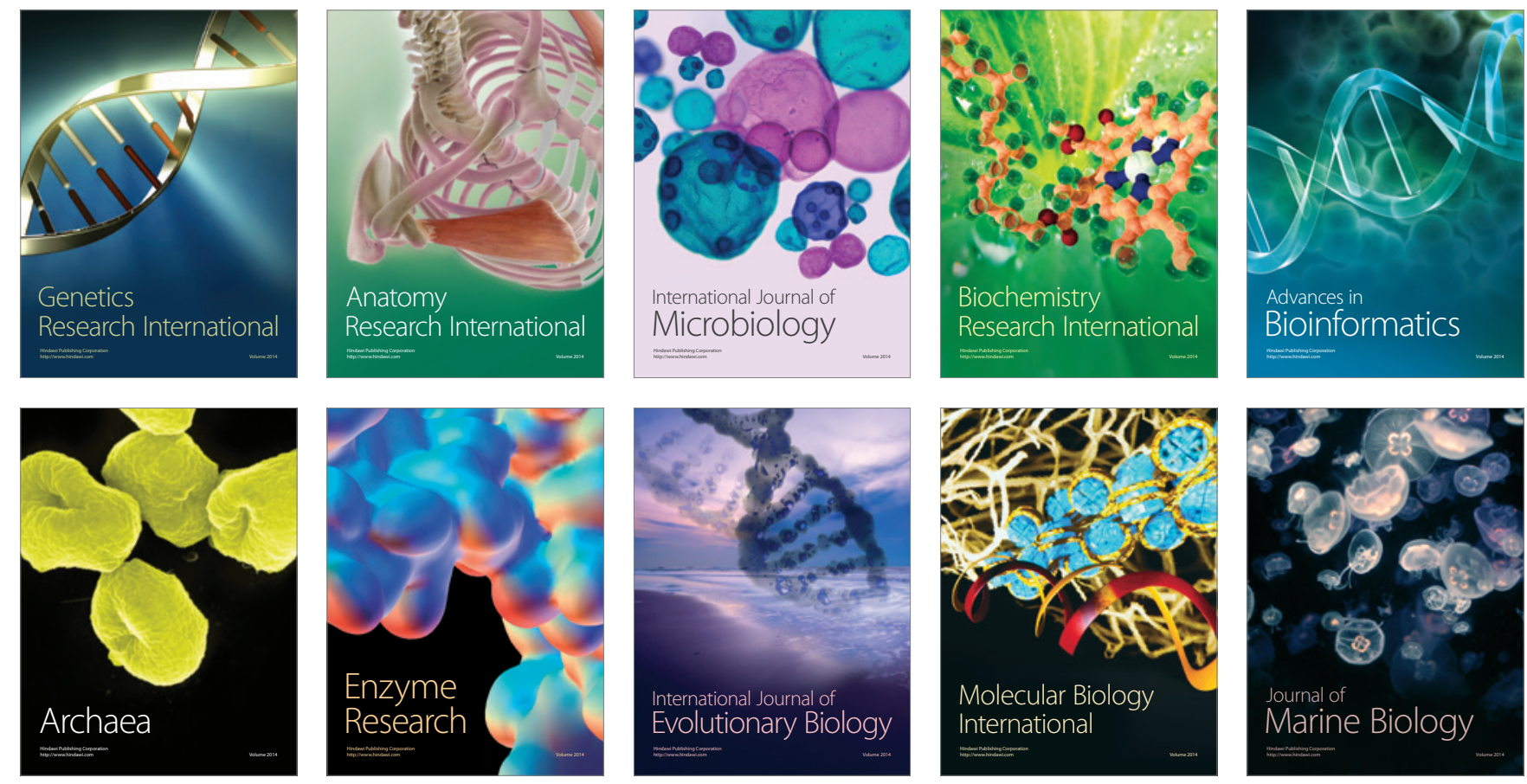